\title{
The Freedom From Sexploitation Agenda: Policy And Legislative Recommendations To Curb Sexual Exploitation
}

\author{
Dawn Hawkins \\ National Center on Sexual Exploitation, info@ncose.com
}

Follow this and additional works at: https://digitalcommons.uri.edu/dignity

Part of the Civic and Community Engagement Commons, Civil Rights and Discrimination Commons, Community-Based Learning Commons, Community-Based Research Commons, Constitutional Law Commons, Criminal Law Commons, Criminal Procedure Commons, Criminology Commons, Domestic and Intimate Partner Violence Commons, First Amendment Commons, Gender and Sexuality Commons, Inequality and Stratification Commons, Internet Law Commons, Law and Politics Commons, Law and Society Commons, Legal Remedies Commons, Legislation Commons, Politics and Social Change Commons, and the Social Control, Law, Crime, and Deviance Commons

\section{Recommended Citation}

Hawkins, Dawn (2017) "The Freedom From Sexploitation Agenda: Policy And Legislative Recommendations To Curb Sexual Exploitation," Dignity: A Journal of Analysis of Exploitation and Violence: Vol. 2: Iss. 3, Article 12. https://doi.org/10.23860/dignity.2017.02.03.12

This Freedom from Sexploitation: An Agenda is brought to you for free and open access by DigitalCommons@URI. It has been accepted for inclusion in Dignity: A Journal of Analysis of Exploitation and Violence by an authorized editor of DigitalCommons@URI. For more information, please contact digitalcommons-group@uri.edu. 


\section{The Freedom From Sexploitation Agenda: Policy And Legislative Recommendations To Curb Sexual Exploitation}

\section{Keywords}

sexual exploitation, pornography, prostitution, sex trafficking, commercial sex acts, obscenity, Internet, communication law, US military, strip clubs, public health, policy, recommendations, agenda, the demand, broadcast guidelines, privacy, sexual abuse, child sexual abuse

\section{Creative Commons License}

\section{(c) (1) $\Theta(\Theta$}

This work is licensed under a Creative Commons Attribution-Noncommercial-No Derivative Works 4.0 License. 


\section{DIGNITY}

Volume 2, Issue 3, Article 12, 2017
A JOURNAL ON

SEXUAL EXPLOITATION

AND VIOLENCE

\section{THE FREEDOM FROM SEXPLOITATION AGENDA \\ POLICY AND LEGISLATIVE RECOMMENDATIONS TO CURB SEXUAL EXPLOITATION}

National Center on Sexual Exploitation

\section{KEYWORDS}

sexual exploitation, pornography, prostitution, sex trafficking, commercial sex acts, obscenity, Internet, communication law, US military, strip clubs, public health, policy, recommendations, agenda, the demand, broadcast guidelines, privacy, sexual abuse, child sexual abuse

$\mathrm{T}$

IHE FREEDOM FROM SEXPLOITATION AGENDA seeks to create a foundation for comprehensive efforts to address various forms of sexual exploitation. It is not a final list of recommendations encompassing all needed reforms. The Agenda will expand or contract as new legislative and policy measures are proposed and implemented. If you have suggestions for The Agenda, please contact the National Center on Sexual Exploitation at public@ncose.com. Please visit SexploitationFreedomAgenda.com for updates.

\section{The Freedom from Sexploitation Agenda}

1. Amend Section 230 of the Communications Decency Act (CDA) of 1996 to allow prosecution of those who facilitate illegal commercial sex acts via the Internet. While the overarching purpose of the CDA was to protect children from exposure to Internet pornography, section 230 of the Act was written to protect Internet companies from being held responsible for content generated by third-party users. The Supreme Court overturned the CDA with the exception of Section 230.

Ironically, courts have recently interpreted section 230 of the CDA as shielding sex trafficking and prostitution websites from criminal and civil liabilities in cases involving the facilitation of sex trafficking via the Internet. As a result, sex trafficking is flourishing on the Internet, and those profiting from the sexual exploitation of countless individuals have repeatedly escaped justice.

2. Instruct the U.S. Attorney General to vigorously enforce current federal obscenity laws, 18 U.S.C. \$ 1460 to 18 U.S.C. \$ 1470. The government can curb the demand for prostitution, sex trafficking, child sex abuse, and sexual violence by demanding the Attorney General enforce these existing federal laws, which prohibit distribution of hardcore pornography on the Internet, on cable/satellite TV, on hotel/motel TV, in retail shops, and by common carrier.

3. Require that training programs informing military personnel about the harms of pornography be incorporated in anti-sexual assault trainings 
across all Department of Defense agencies. Institute routine audit and removal of pornography found on military computers, storage drives, work areas, and officer's clubs, across all branches of the U.S. military.

4. In furtherance of the Department of Defense's “2015 Combating Trafficking in Persons (CTIP) Instruction 2200.1," institute a rule making strip clubs off-limits to all U.S. military personnel worldwide. Strip clubs provide the perfect learning environment for sexually toxic attitudes and behaviors. Leering, jeering, sexual touching, lap dancing, acts of prostitution, sexual assaults, and sexual trafficking are everyday occurrences in strip clubs around the world. Military personnel participating in the consumption of commercial sex at strip clubs fuel the demand for sex trafficking. Moreover, military members cannot exploit and objectify women in one environment without it having a deleterious effect on other aspects of their lives, including their military service.

5. Direct the U.S. Surgeon General and the U.S. Department of Health and Human Services to fund research into the public health harms of pornography, and launch comprehensive efforts to abate these problems. Specific research and program areas include, but are not limited to, the following:

- a nationally representative survey of pornography use among adolescents and adults;

- a meta-analysis of the neurological studies linking pornography use to compulsive behaviors;

- the association between adult pornography use and child sexual exploitation;

- the association between pornography consumption and sexual violence generally, and violence against women in particular;

- the association between pornography use and sex buying behaviors;

- the association between pornography use and child-on-child sexual abuse;

- pornography's impacts on other sexual behaviors and attitudes among adolescents and adults;

- the impacts of pornography use on intimate relationships;

- the link to erectile and sexual dysfunctions;

- $\quad$ transmission of STDs;

- detrimental impacts on brain health; etc.

6. As the 2013 Trafficking in Persons Report observed, "If there were no demand for commercial sex, sex trafficking would not exist in the form it does today. This reality underscores the need for continued strong efforts to enact policies that prohibit paying for sex." Thus, it is imperative that DOJ, under the provisions of the Justice for Victims of Trafficking Act, prosecute those who "solicit or patronize" victims of human trafficking for the purpose of commercial sex 
acts. DOJ should also work with its federally funded anti-trafficking task forces to ensure the investigation, arrest, and prosecution of persons who purchase sexual acts, as part of a concerted effort to combat the demand for sex trafficking. DOJ must also work to ensure that its grantees support efforts to enforce state and local laws criminalizing the purchase of commercial sex, and reallocate and prioritize resources so that demand reduction efforts such as those undertaken in King County, Washington, and by Cook County Sheriff Tom Dart are replicated across the country.

7. Preserve National Security Presidential Directive-22 (NSPD-22). NSPD-22 instructs federal agencies to strengthen their collective efforts to combat trafficking in persons; adopt an abolitionist approach to combating human trafficking by recognizing that activities such as prostitution, pimping, pandering, and maintaining of brothels contribute to the phenomenon of trafficking in persons; and formalizes the U.S. government's opposition to prostitution and related activities as inherently harmful and dehumanizing.

8. Immediately nominate an individual to the position of Ambassador-atLarge for Trafficking in Persons at the U.S. Department of State who is committed to combating all forms of human trafficking (sex and labor trafficking), and who will address the role of demand for commercial sex in the crime of sex trafficking and vigorously support National Security Presidential Directive-22.

9. Direct the Departments of Justice, State, and Health and Human Services, as well as USAID to provide guidance to U.S. states and foreign governments advising against the decriminalization of prostitution and against the normalization of prostitution as "sex work." Multilateral organizations such as the UN Women and UNAIDS, as well as organizations like Amnesty International and the Open Society Foundation, are pushing for the full decriminalization of prostitution in the U.S. and abroad. Full decriminalization of prostitution transforms pimps and sex traffickers into "business entrepreneurs," and institutes a de facto right for men to buy women, men, and children for sex. Such laws do not protect the human rights of persons in prostitution, but guarantee that their dehumanization and exploitation will continue.

10. Pass H.R. 466 "Sex Trafficking Demand Reduction Act." Specifically, this bill amends the Trafficking Victims Protection Act of 2000 regarding the determination of whether a government has made serious and sustained efforts to reduce the demand for commercial sex acts. Pursuant to the minimum standards for the elimination of sex trafficking, if a government has the authority to prohibit the purchase of commercial sex acts, but fails to do so, it shall be deemed a failure to make serious and sustained efforts to reduce the demand for commercial sex acts, irrespective of other efforts the government may have made.

11. A recent meta-analysis of 22 studies from seven countries provides clear evidence confirming that pornography exposure is significantly associated with sexual aggression. ${ }^{1}$ As the authors stated, "the accumulated data leave little doubt that, on the average, individuals who consume pornography more frequently are more likely to hold attitudes conducive to sexual aggression and engage in actual acts of sexual aggression than individuals who do not consume pornography or who consume pornography less frequently."2

${ }^{1}$ Paul J. Wright, Robert S. Tokunaga, and Ashley Kraus. “A Meta-Analysis of Pornography Consumption and Actual Acts of Sexual Aggression in General Population Studies.” Journal of Communication, (December 29, 2015): 1-23.

${ }^{2}$ Ibid. 
Additionally, a nationally representative survey of pornography use among youth aged 9-17, found that those with increased exposure to Internet pornography were significantly more likely to report physical and sexual victimization. ${ }^{3}$ A separate study of 14- to 19-year-olds found that females who watched pornographic videos were at significantly greater likelihood of being victims of sexual harassment or sexual assault. 4 A study of 804 Italian males and females aged 14 to 19 , found that males who viewed pornography were significantly more likely to report having sexually harassed a peer or forcing someone to have sex.5

Thus, we strongly encourage the Office on Violence Against Women (OVW) and the U.S. Department of Education (DOE) to review their institutional policies and practices for ways in which they can share research, provide educational materials, and institute policies, regarding pornography's role in exacerbating sexual violence. We call particular attention to OVW's obligations under the Sexual Assault Services Program, and DOE's obligations under the Clery and Campus Sexual Violence Elimination Acts, and request that OVW and DOE institute new reporting, research, and programmatic initiatives, regarding the association between pornography consumption and sexual violence.

12. Pass H.R. 680 “Eliminating Pornography from Agencies Act.” Several investigations have found that some federal employees view hardcore pornography at work-in at least one case for as many as six hours a day for several years. Some federal employees also have admitted to storing tens of thousands of pornographic images on their office desktops. Accordingly, this bill would require the Office of Management and Budget to issue guidelines that prohibit the access of pornographic or other explicit websites from a federal computer (not applicable for computers used for investigative purposes that require visiting a pornographic website).

13. Direct the Federal Communications Commission to vigorously enforce the federal indecency law, 18 U.S.C. $\$ 1464$, designed to protect children from damaging sexual content on television and appoint FCC commissioners committed to fulfilling this mission.

14. Disband the current TV Parental Guidelines Oversight Monitoring Board (TVOMB). The TVOMB has enabled and sheltered a flawed content ratings system, rather than following its congressional and FCC mandate to ensure the accuracy and integrity of the system. The current TVOMB is a sham composed of broadcast television insiders, and is utterly lacking in congressional oversight and public transparency. Accordingly, review and revision of the statutes under which the TVOMB is organized is essential to achieving consistency, transparency, accuracy, and accountability, as well as to protecting the well-being of America's children.

3 Michele L. Ybarra and Kimberly Mitchell, "Exposure to Internet Pornography among Children and Adolescents: A National Survey,” CyberPsychology \& Behavior 8, no. 5 (2005): 473-486.

${ }^{4}$ Silvia Bonino, Silvia Ciairano, Emanuela Rabagliette, and Elena Cattelino, "Use of Pornography and Self-Reported Engagement in Sexual Violence among Adolescents," European Journal of Developmental Psychology 3, no. 3 (2006):265-288.

${ }^{5}$ Silvia Bonino, Silvia Ciairano, Emanuela Rabagliette, and Elena Cattelino, "Use of Pornography and Self-Reported Engagement in Sexual Violence among Adolescents," European Journal of Developmental Psychology 3, no. 3 (2006):265-288. 
15. In 2005, Congress passed the Family Movie Act (FMA), which granted families the right to filter offensive content in movies for private home viewing. Today the preferred method for viewing movies has shifted from DVD to streaming video. Hollywood has seized this opportunity to once again attack filter providers with (a) litigation against a leading streaming filtering company, (b) contractual clauses with streaming providers to prohibit filtering, and (c) opposition to protecting streaming under the Family Movie Act. To preserve the right of parents to shield their children from harmful content, Congress should update the FMA to explicitly include streaming.

16. Pass S.534 "Protecting Young Victims from Sexual Abuse Act of 2017." In light of recent allegations of sexual abuse against personnel involved with USA Gymnastics, USA Swimming and USA Taekwondo, this bill would require amateur athletics governing bodies to immediately report sex-abuse allegations to local or federal law enforcement, or a child-welfare agency designated by the Justice Department. The measure would also amend the Ted Stevens Amateur and Olympic Sports Act, which governs amateur athletics governing bodies, to make it safe and easy for victims to report abuse and mandate oversight of member gymnasiums to ensure strong sexual abuse prevention policies are implemented.

\section{AUTHOR BIOGRAPHY}

The National Center on Sexual Exploitation (NCOSE) is the leading national organization addressing the public health crisis of pornography and exposing the links between all forms of sexual exploitation. NCOSE embraces a mission to defend human dignity and to oppose sexual exploitation. To this end, NCOSE operates on the cutting edge of policy activism to combat corporate and government policies that foster exploitation and to advance public education and empowerment.

\section{RECOMMENDED CITATION}

National Center on Sexual Exploitation. (2017). The freedom from sexploitation agenda: Policy and legislative recommendations to curb sexual exploitation. Dignity: A Journal of Sexual Exploitation and Violence. Vol. 2, Issue 3, Article 12. DOI:10.23860/dignity.2017.02.03.12. Available at http://digitalcommons.uri.edu/dignity/vol2/iss3/12. 